\title{
IMPACT OF PIRACY AND SEA ROBBERIES ON FISHING BUSINESS IN NIGERIA: A FOCUS ON LAGOS COASTAL AREA
}

\author{
Abdullahi Saheed USMAN \\ Department of Management Technology, College of Management Sciences \\ Bells University of Technology, Ota, Nigeria \\ Oluwaseyi Joseph AFOLABI \\ Department of Management Technology, College of Management Sciences \\ Bells University of Technology, Ota, Nigeria \\ afolabiseyo@yahoo.com \\ NWOYE Casmier Friday \\ Department of Management Technology, College of Management Sciences \\ Bells University of Technology, Ota, Nigeria
}

\begin{abstract}
Nigeria as a littoral state with a coastline of slightly above 800 kilometers and located in the Gulf of Guinea (GoG) region puts the government in a position that requires her to deploy resources to combat the menace of piracy and sea robbery. Pirate activities affected not only the maritime transport sector, but the other forms of maritime economic activities. The fishing industry also got her fair share of this menace despite the contribution of the industry to the society. The activities of pirates and sea robbers and their impacts on fishing industry in Lagos coastal area was investigated using structured questionnaire deployed to relevant stakeholders in the fishing business in Lagos area. This research interrogates possible factors that create the enabling environment for piracy to flourish. The study revealed that the inability of government to effectively curb activities of these criminals was to some extent influenced by corruption, poverty and inequality in the society. Financial loss to the nation due to the menace was found to be alarming and has forced several fishing companies out of business to the extent that only few fishing vessels (trawlers) are currently in operation in the area of study. The research confirmed negative effects of piracy on sea businesses, particularly fishing activities, which was the crux of this investigation. The study recommends, amongst others, the Nigerian government should evolve sound resource management and equitable allocative practices to leverage the enormous natural resources and oil affluence to effectively address the cacophony of economic afflictions and legal framework should be revisited, reviewed, reformed and harmonized.
\end{abstract}

Keywords: Maritime, Piracy, Fishing, Trawling, Coastal Areas 


\section{INTRODUCTION}

Maritime piracy has been a menace to the sea fearers for centuries. This unwholesome activity has been taking place for centuries with negative impact on the world maritime trade. Wherever piracy occurs, it has been observed to have the same cause but differs in mode of execution. Piracy has never been observed as a friend to the maritime industry. Rather, it is considered an enemy in the maritime domain and indeed, of the sea transportation. It is also considered an enemy to the world economy and enemy to the consumers, which has to be fought. The advancement of technology has made piracy of today very different from ancient sea piracy. Commensurately, combating modern day piracy by the world has employed appropriate technology (Mandanda \& Ping, 2016).

The advent of militancy in the Niger Delta region of Nigeria in the late nineties fueled the increased activities of pirates in the Niger Delta area and coastal areas of Nigeria. The increase is mostly related to the upsurge in the activities of ethnic militants in Nigeria's oil-rich Niger Delta region, who were protesting perceived marginalization of the region by successive governments in Nigeria. This led to an increase in the number of attacks and hostage taking between 2006 and 2008 (Onuoha, 2010). When attacks result in hostage situation, captivity period for hostages vary, but of captivity lasts an average of ten days as compared to six months for Somali hijackings (Onuoha, 2010).

In its 2010 annual report, International Maritime Organization (IMO) listed the West African coast among the top six piracy hotspots in the world. According to IMO in 2012, 58 attacks were reported in the region during the first 10 months of 2011, minding the fact that fishing industry being the second largest industry in maritime is having a large share of these attacks. The fishing industry plays crucial roles in the economic development of the country but inherent dangers and adverse consequences of piracy on the industry has caused a lot of financial and economic loss in the industry. The resultant insecurity at sea has affected fishing infrastructure, economy and wellbeing of stakeholders in the industry.

\section{MARITIME PIRACY AND SEA ROBBERY}

Piracy in the maritime domain has been classified, together with others (war crimes and crimes against humanity) as universal crime under the international law. This mandates all nations to arrest and punish maritime pirates caught committing the act on the high seas (Anene, 2006). Piracy under international context, has firstly been defined by the 1958 Geneva Convention on the high seas, as "illegal acts of violence, detention or depredation committed for private ends by the crew or passengers of a private ship or private aircraft and directed against another ship or aircraft or against persons or property onboard such ships or aircraft on the high seas which is outside of jurisdiction of any State". This 
Usman A. S., Afolabi O. J., Nwoye C. F.

IMPACT OF PIRACY AND SEA ROBBERIES ON FISHING BUSINESS IN NIGERIA:

A FOCUS ON LAGOS COASTAL AREA

definition has later in 1982 United Nations Convention on the Law of the Sea article 101, been confirmed and adopted. Definition of piracy in the international law has emerged as a discussion particularly on the geographical location of the place where piracy activities are considered to have taken place (Anene, 2006; Mandanda, 2016).

This definition is considered to be narrow as it has left no room for the activities of the same nature happening elsewhere than on the high seas. The definition excludes all similar activities happening in the territorial waters of a State and within the Exclusive Economic Zone (EEZ) of a State where no other State than the territorials shall have jurisdiction over the matter, and International Law could not apply but Municipal Laws of the littoral State where the piracy activities are taking place. Where acts of violence against sea farers occur within the territorial areas of the state, is referred to as sea robbery. Piracy activities happening in the Gulf of Guinea elicits mixed thoughts amongst scholars on whether the same fit into the international law definition of piracy or not (Mandanda, 2016).

\section{THE DEVELOPMENT NEXUS OF PIRACY AND SECURITY}

It is generally believed that combination of a number of factors account as reasons for piracy to thrive in some areas. Some of the reasons include economic hardship, political instability or absence of constituted authority and high level of poverty. Maritime piracy frequently has its roots in weak or fragile states, where humanitarian conditions are dire and economic opportunities are limited. Roger Middleton (2008) averred "The economic hardship in Somalia and absence of an effective legal regime or enforcement agency has meant anyone who could get their hands on a boat could become a pirate, and many have done so". Also, Maximo Q. Mejia Jr. (2012) in a paper titled Exploring Linkages Between Economic Development, Political Stability and Maritime Piracy stated, "Perhaps because the link between economic development, socio-political stability/security, and piracy is seen as self-evident, there does not seem to be a great deal of effort into investigating the connection".

\section{NIGERIA MARITIME CRIME ACTIVITIES}

Piracy remains elusive and continues to endanger the properties and lives of seafarers. This enduring practice has been around for centuries. Currently, it has placed security spotlight on the Nigeria water ways and frantic efforts made by the government to combat the menace proved evasive. From late 1990s, when militancy began in the Niger Delta, the region has been facing acts of piracy targeting high-value assets, particularly oil and fish shipments. The incidents of piracy and armed robbery in the area rose significantly in 2010 , making the region the second most acute piracy prone area on the 
African continent. In its 2010 annual report, International Maritime Organization (IMO) listed the West African coast among the top six piracy hotspots in the world.

As response to the menace of piracy increase, pirates increasingly modify their tactics. The desire by the pirates to extend their reach beyond the immediate coastal areas of the littoral states have seen them change tactics to hijacking fishing vessels or tug boats, particularly within Nigerian waters, and using same to attack other vessels operating deeper offshore Nigeria and also off the coasts of neighboring countries like Benin, Togo and Cameroun. Even though the littoral states of the Gulf of Guinea $(\mathrm{GoG})$ share the common threat from activities of pirates, the territorial waters of Nigeria, Benin and Togo are considered areas at greatest risk of various forms of waterborne criminalities. These criminalities, in some instances, extend to their exclusive economic zones (EEZs).

\section{ILLEGAL, UNREPORTED AND UNREGULATED (IUU) FISHING}

It is estimated that about $40 \%$ of fishing in West Africa qualifies as illegal, unreported and unregulated (IUU) fishing. This fact rarely features heavily in discussions of maritime security in the Gulf of Guinea but is of critical economic significance for West African governments, who collectively lose as much as $\$ 1.5$ billion annually to IUU fishing. Most of the illegally caught fish from West Africa have ready markets in European Union and Asian markets. This makes it important to some international actors as evidence exists of links between vessels involved in IUU fishing and other forms of seaborne organized crimes, including drug-smuggling. In April 2006, a pirate ship, MV "Binar 4" with 200 tons of illegal and stolen fish from West African waters were detained in Spain after chasing her over 1000 nautical miles. Similarly, Oleg Naidenov, a Russian trawler was detained in Dakar on January 5, 2014 after the trawler was observed fishing illegally in Senegalese waters. IUU activities in West African waters are so significant that experts said, "West Africa's fish stocks are being depleted by industrial trawlers which comb the oceans to feed European and Asian markets". According to a recent study published in Frontiers in Marine Science journal, Illegal, unreported, and unregulated (IUU) fishing costs West African economies stunning $\$ 2.3$ billion a year.

While illegal unregulated and unreported (IUU) fishing contributes to the low domestic fish production, piracy in Nigeria's territorial waters significantly affects the fishing industry in the country. Despite the attempt by Nigerian government to secure its maritime zones, piracy has continued to thrive, posing a serious challenge to fisheries, especially to research and scientific initiatives, to fish population and the size of fish stocks, to fisheries management and at-sea observations, to fishing practices, to the economic viability of fishing enterprises, to livelihoods and food security, to revenue to the government 
and to other allied industries. Aside from Nigeria, piracy has similar "...impact on countries like the Seychelles, which relies on the fishing industry for up to $40 \%$ of its earnings" (Onuoha \& Habiba, 2009). The incidence and effect of piracy on the fishing industry was aptly illustrated by the event that took place early in 2008, when the fishing industry in one of the coastal states in Nigeria, Akwa Ibom, was paralyzed in a wave of extortion and boat hijack executed by pirates. The attacks forced trawlers to go on an indefinite strike, bringing the local economy to a standstill and causing huge loss of revenue to the state (Adedeji \& Okocha, 2008). While this particular situation was eventually resolved, security remains just one of the several intractable challenges restraining the expansion of Nigerian fishing industry. These pirate attacks also have humanitarian effect as fishermen are injured or killed in the process of hijacking their trawlers. For example, in 2003, there were 107 attacks on fishing trawlers, while in January 2008 alone, 50 attacks took place, and over 64 attacks were recorded in October 2008; in the process, some fishermen would have been either injured or killed. Presently, the incessant piratical attacks and hijack of trawlers, which are eventually used by pirates as mother ships for further attacks, have tremendous effect on the fishing industry in Nigeria (Rashid, 2012).

\section{CAUSES AND EFFECTS OF PIRACY ON THE FISHING INDUSTRY IN NIGERIA}

- Underdevelopment of the Oil Producing Communities

One of the major causes of piracy is the underdevelopment of the coastal areas. Against this backdrop, the Niger Delta youths in the South-South Nigeria have been very restive due to complete neglect of the region by each successive government. There is overwhelming infrastructural neglect in the coastal communities, coupled with the devastation of the environment as a result of activities of oil exploration in the area. Despite the fact that about 95 percent of Nigeria's revenue comes from the region, it has been subjected to all forms of infrastructural decadence. This has been made worse by environmental pollution, like oil spillage, which destroys the agricultural potentials of the coastal areas, including fishing and farming.

- Environmental Degradation of the Oil Producing Communities

Due to the activities of oil and gas exploration, the environment of the host communities is severely destroyed. As a result of this, the ecosystem is devastated. According to a Shell sponsored report, due to decades of oil and gas exploration in the Niger Delta area, the environmental stress has increased, and livelihoods have been impacted by a combination of these factors, as well as lingering residues of pollutants (Gland, 2013). This situation has not provided a conducive environment for the recovery and return of biodiversity. The pollution of the environment adversely affects fishing and farming, thereby 
aggravating poverty and unemployment which culminates to increased restiveness among the youth of the Niger Delta region, creating an enabling environment for piracy and other maritime crimes to thrive.

- Existence of Organized Crime

Piracy in Latin American countries occurs where shipping routes coincide with routes used for trafficking in illegal commodities, particularly drugs, illegally extracted raw materials, human and arms. This affects the maritime border between Colombia and Venezuela, Haiti and Jamaica, among others. Wellestablished smuggling routes run through these areas and are used in exporting cocaine to the United States and Europe. The intermediaries of the cocaine trade possess speedboats and heavy weaponry, creating an incentive to utilize the equipment for other purposes, like piracy. In the Gulf of Guinea, there are also smuggling routes for arms and ammunitions, narcotics, among other things, to Europe and North America (Foreign Affairs Council Meeting, 2014).

- Poverty and Unemployment

In addition to lack of infrastructural development of the oil producing areas, 70 percent of Nigerians live below the poverty line amid abundant natural resources (Barrios, 2013) Aside from poverty, the teeming youths from the oil producing areas are unemployed which exposes them to criminal activities like piracy. This situation is similar in many other African countries particularly in the Gulf of Guinea where the youths in a well-coordinated scheme get involved in piracy as a means of survival. Poverty and unemployment which have given fillip to piracy is a common feature in Indonesia. Thus, poverty and unemployment lead to piracy.

\section{EFFECTS OF PIRACY ON THE FISHING INDUSTRY IN NIGERIA AND OTHER COUNTRIES}

- Humanitarian Effects

Pirate attacks on fishing trawlers lead to humanitarian consequences when pirates shoot, maim and kill crew members. This situation is aptly demonstrated by an incident that occurred on the 23 April 2014, when armed robbers attacked fishing boats on the lbeno waterways in Akwa Ibom state, Nigeria. The engine of the boat, nets and fish were stolen, while one of the fishermen was shot. Lending credence to the spate of piracy attacks on fishermen, NITOA stated that it lost 4 crew members after 144 piratical attacks on trawlers in 2012 (Shipping Position, 2013). Nincic has observed that pirate attacks on fishing vessel have resulted in the killing of fishermen. Aside from fishermen, pirates also hijack oil tankers, while crewmembers are injured and kidnapped in the process in Nigerian waters. The attack on a fishing trawler, Sherry Fishing Dhow, by Somali pirates on the Indian Ocean, in which extreme violence 
Usman A. S., Afolabi O. J., Nwoye C. F.

IMPACT OF PIRACY AND SEA ROBBERIES ON FISHING BUSINESS IN NIGERIA:

A FOCUS ON LAGOS COASTAL AREA

was used against the crew, by firing at them using AK 47 rifle and a pistol, and subsequently taking control of the trawler, endangered the lives of the crew members (Chang, 2010).

- Economic Effect

Piracy also imposes significant costs on the Nigeria's important local fishing economy. Fishing was the second highest non-oil export industry in the country, and pirate attacks on fishing trawlers have reached the point that many fishing boat captains refuse to sail. The attacks range from minor harassment to theft of fish cargoes, engines and other material on board and extortion. It is important to note that pirate attacks worldwide are considered to be vastly under-reported, and Nigeria is no exception, particularly when it comes to attacks on fishing vessels. The Nigerian Inter-agency Maritime Security Task Force on Acts of Illegality in Nigerian Waters (IAMSTAF) reported at least 293 documented sea robberies and pirate attacks between 2003 and 2008 on the country's fishing vessels alone.

- Health Effect

In addition to the impact on Nigeria's export economy, seafood prices have skyrocketed due to the scarcity of fish caused by fewer fishing vessels being willing to put to sea. Prices have more than doubled and even quadrupled in some places, placing this important protein source out of the reach of most of the average citizens. This situation is also peculiar to other Gulf of Guinea countries. For example, fish stocks are an important source of protein for the region. Piracy jeopardizes the nutritional value derived from the fishing industry, and this culminates to other health challenges like malnutrition, obesity, diabetes, among others (Chatham House, 2013).

- Socio-Political Effect

As of March 2008, over 170 fishing trawlers were idle because fishing boats were afraid to put to sea, threatening approximately 50000 jobs. The consequence of this is that Nigeria stands to lose up to US\$600 million in export earnings due to piracy threats to its fisheries. More so, many fishing companies are relocating to other countries, while others are closing down completely as a result of piracy in the territorial waters of Nigeria (llufoye, 2009). It is evident, therefore, that the disruption of fishing activity due to piracy portends grave danger to the socio-political and economic development of Nigeria and other Gulf of Guinea countries. In Seychelles, for instance, the fishing industry, as well as tourism, provides employment for 36 percent of the country's workforce, and piracy adversely affects it.

\section{METHODOLOGY}

\subsection{Study area}


Usman A. S., Afolabi O. J., Nwoye C. F.

The study area covers the fishing fields that extend from the coastline of Lagos state to deep water areas. Fishing companies existing in the metropolis were in scope. Metropolitan Lagos extends over sixteen (16) of the twenty (20) Local Government Areas of Lagos State, and contains $88 \%$ of the population of Lagos State. Lagos is the smallest and most important city in the Federation of Nigeria. The country, which is located in the coast of West Africa, consists of 36 states and a capital territory. Nigeria shares borders with Benin, Cameroon, Chad and Niger. Lagos is one of the important cities in Nigeria, which is situated in the south-western coast of Nigeria.

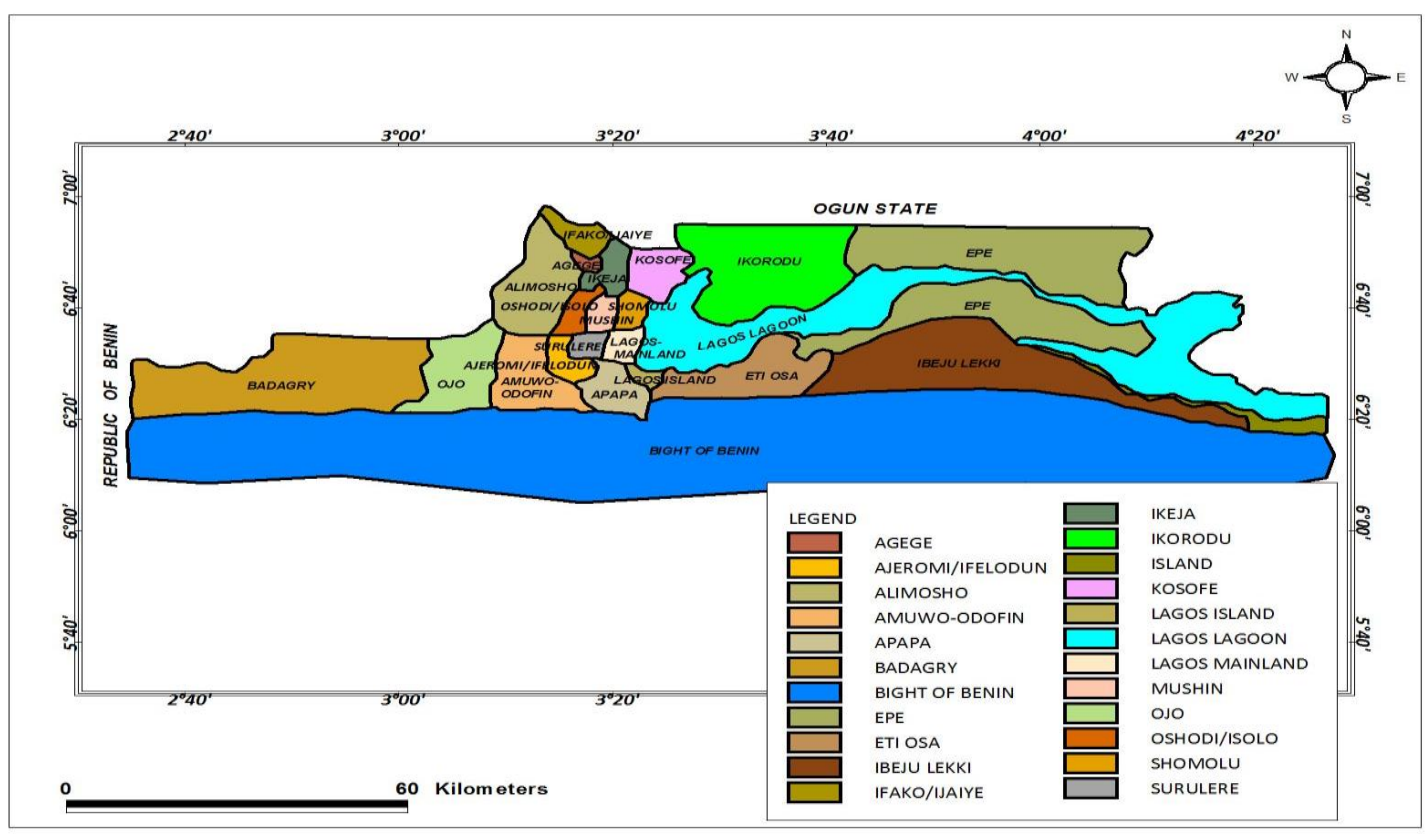

FIGURE 1. ALL THE LOCAL GOVERNMENT AREA IN LAGOS

Source: Authors' representation

\subsection{Population of the Study}

The population of study is a census of all items or subjects that possess the characteristics or that have the information, of the event being studied (Cosby, 2000). The study population comprises the Nigerian Trawler Owners Association, the trawling companies, NIMASA and Nigeria Navy (Western Naval Command). They were selected because they represent key stakeholders in the fishing industry in many ways and appropriate to be the respondents of the study.

\subsection{Data Analysis}

Identification and mapping of piracy inlets in Lagos 
Usman A. S., Afolabi O. J., Nwoye C. F.

IMPACT OF PIRACY AND SEA ROBBERIES ON FISHING BUSINESS IN NIGERIA:

A FOCUS ON LAGOS COASTAL AREA

Over the years, Lagos has witnessed the emergence and consolidation of what can be aptly termed as "the triad axis of maritime terrorism". These pirates have successfully couched a den from where their nefarious activities mostly emanate and terminate. Among the triumvirate shoreline inlets, the Epe axis has emerged to be most sophisticated, organized and brutish. It outsets at Langbasa in Epe coastal forest stretching through the thick forest all the way to Awoye in Ondo State. Tarkwa Bay seemingly appears constricted and minimal in geographic extent; resembling more of an outpost for spying, petty and impulse attacks. Yet, they have been known to be equally dangerous and potent at the slightest opportunity to attack when the tendencies of been caught is low. The narrow sparing forest at the coast from Seme in Badagry up to Califux, Benin Republic represents the newest potent pirate's inlet that has emerged since the turn of year 2000. However, these pirates across the Lagos triad shoreline inlets operate on mutual respect in terms of vessel targets and territorial extent. They have been seen engaged in collaborative efforts in spite of been on collision course at some other times. These results are viewpoint strongly supported by the Nigerian Navy and focus group discussants. The said inlets are pictorially mapped in Fig 2 below.

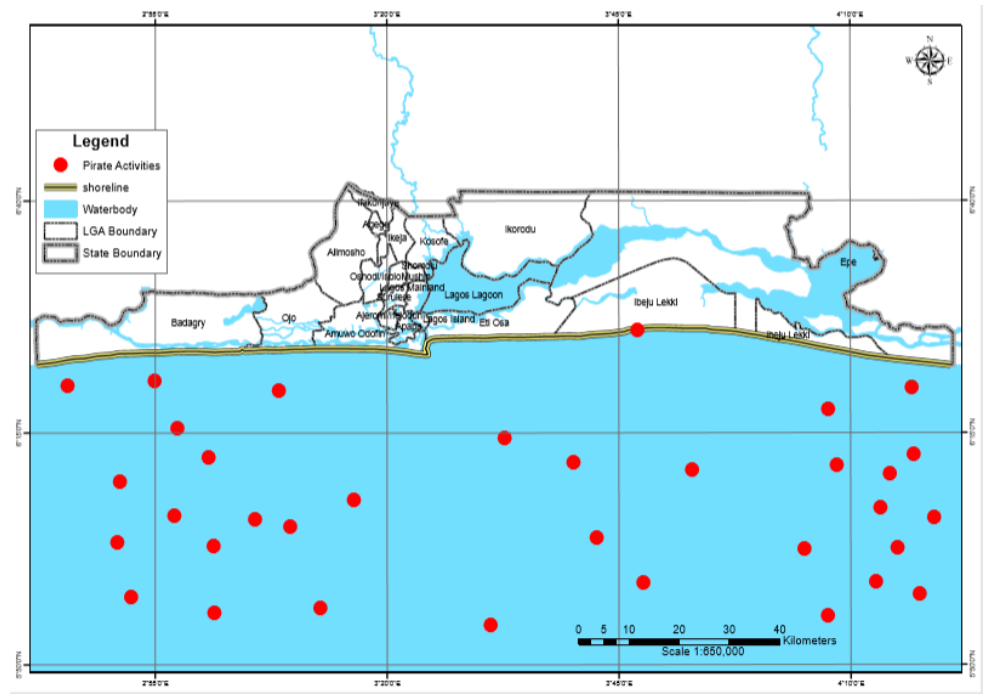

FIGURE 2. PIRATE INCIDENTS IN LAGOS STATE

Source: Author's extraction of ArcGIS, 2019 
Usman A. S., Afolabi O. J., Nwoye C. F.

IMPACT OF PIRACY AND SEA ROBBERIES ON FISHING BUSINESS IN NIGERIA:

A FOCUS ON LAGOS COASTAL AREA

\begin{tabular}{|c|c|c|c|c|c|c|c|c|c|}
\hline \multirow[b]{2}{*}{ Model } & \multirow[b]{2}{*}{$\mathrm{R}$} & \multirow[b]{2}{*}{$\mathrm{R}^{2}$} & \multirow[b]{2}{*}{$\begin{array}{c}\text { Adjusted } \\
\mathrm{R}^{2}\end{array}$} & \multirow[b]{2}{*}{$\begin{array}{l}\text { Std. error of the } \\
\text { Estimate }\end{array}$} & \multicolumn{5}{|c|}{ Change Statistics } \\
\hline & & & & & \begin{tabular}{|l}
$R \quad$ Square \\
Change
\end{tabular} & F Change & df 1 & df 2 & $\begin{array}{l}\text { Sig. F } \\
\text { Change }\end{array}$ \\
\hline 1 & $.892^{3}$ & .795 & .793 & 1.54937 & .795 & 321.985 & 1 & 83 & .000 \\
\hline
\end{tabular}

FIGURE 3. MODEL SUMMARY

Source: Fieldwork, 2019

From the $\mathrm{R}^{2}$ value in figure 3 , it implies that the pirate attacks can explain as $79.5 \%$ of variation in the setback experienced by the fishing industry in Lagos. It also shows that sea piracy effects sea faring and fishing business significantly in Lagos State.

Coefficients

\begin{tabular}{|c|c|c|c|c|c|c|c|c|}
\hline \multirow[b]{2}{*}{ Model } & & \multicolumn{2}{|c|}{ Unstandardized Coefficients } & \multirow{2}{*}{\begin{tabular}{|l} 
Standardized \\
Coefficients \\
Beta
\end{tabular}} & \multirow{2}{*}{ t } & \multirow[b]{2}{*}{ Sig. } & \multicolumn{2}{|c|}{$\begin{array}{l}95.0 \% \text { Confidence } \\
\text { Interval for B }\end{array}$} \\
\hline & & $B$ & Std. Error & & & & $\begin{array}{l}\text { Lower } \\
\text { Bound }\end{array}$ & Upper Bound \\
\hline 1 & $\begin{array}{l}\text { (Constant) } \\
\text { Piracy/sea } \\
\text { robberies }\end{array}$ & $\begin{array}{l}13.401 \\
1.427\end{array}$ & 1.781 & .892 & $\begin{array}{l}7.526 \\
17.944\end{array}$ & $\begin{array}{l}<0.001 \\
<0.001\end{array}$ & 9.859 & 16.943 \\
\hline
\end{tabular}

FIGURE 4. REGRESSION SUMMARY OF IMPACT OF PIRATE ATTACKS ON FISHING ACTIVITIES

Source: Fieldwork, 2019

The significant value derived from above figure 4 is 0.001 . This is far less than the $p$ value of 0.05 . This implies that piracy is significantly impacted by the dependent variables. 
Usman A. S., Afolabi O. J., Nwoye C. F.

IMPACT OF PIRACY AND SEA ROBBERIES ON FISHING BUSINESS IN NIGERIA:

A FOCUS ON LAGOS COASTAL AREA

TABLE 2. EVALUATING THE IMPACT OF PIRACY/SEA ROBBERY ON FISHING ACTIVITIES IN LAGOS STATE

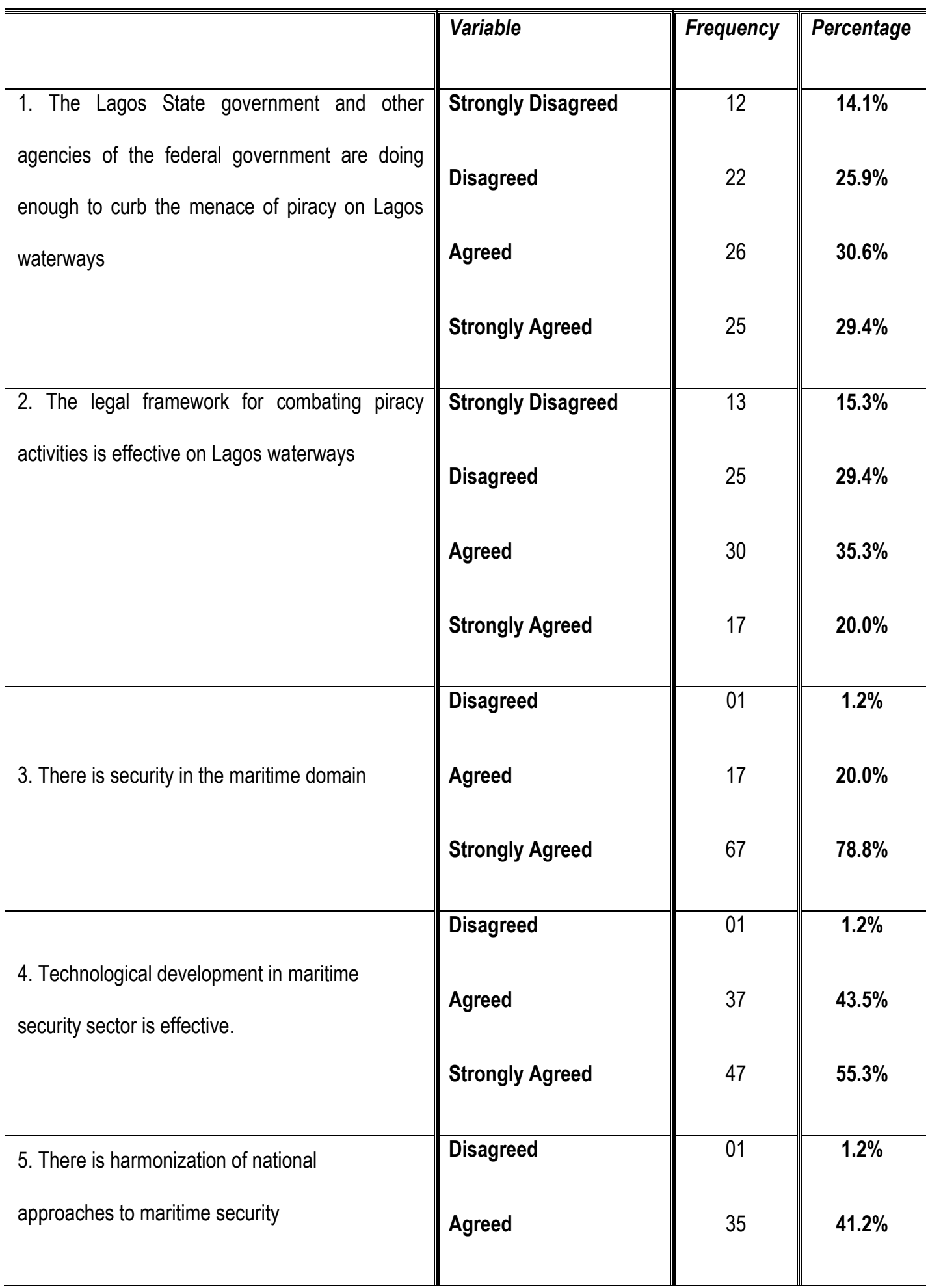


Usman A. S., Afolabi O. J., Nwoye C. F.

IMPACT OF PIRACY AND SEA ROBBERIES ON FISHING BUSINESS IN NIGERIA:

A FOCUS ON LAGOS COASTAL AREA

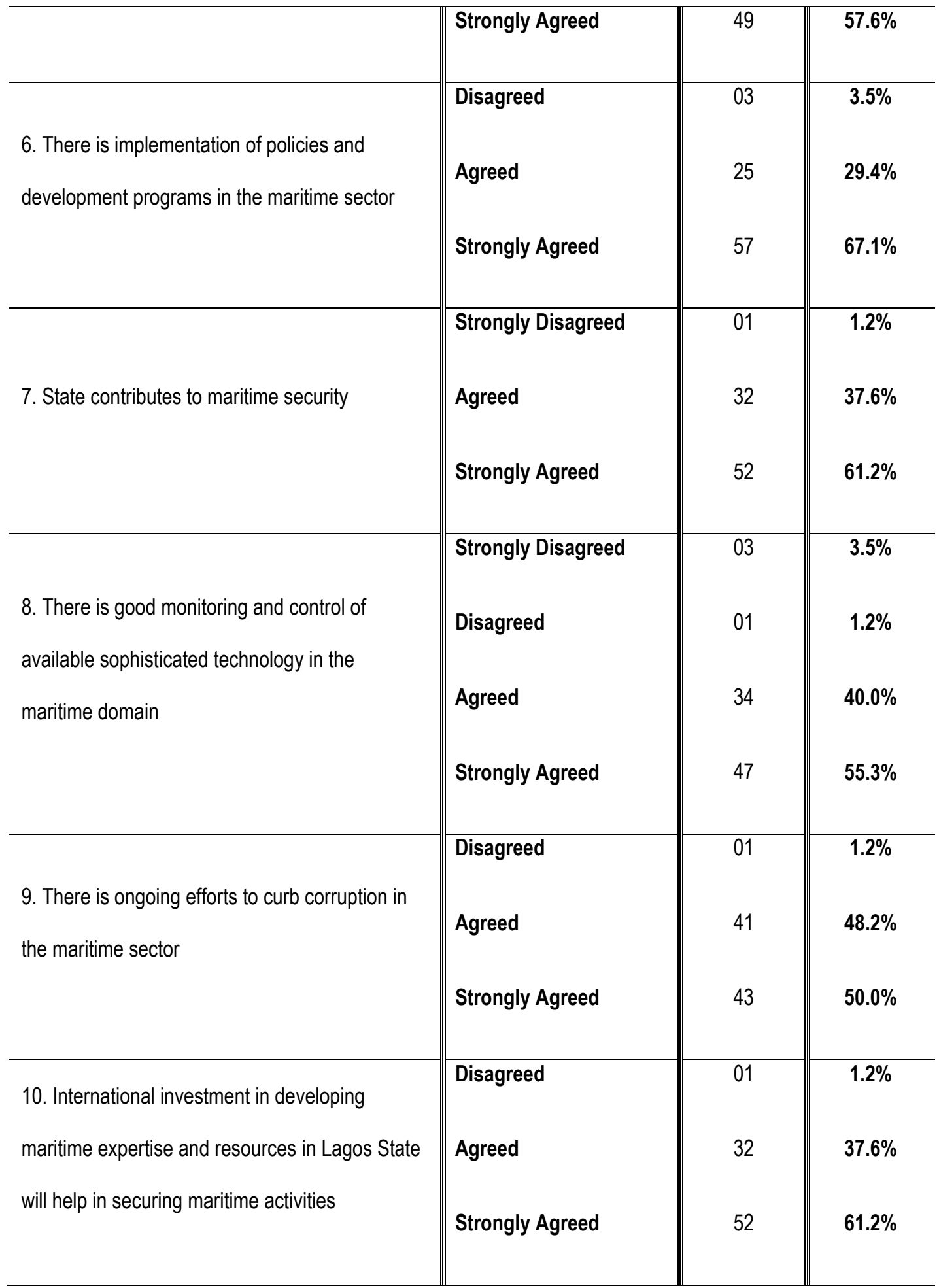

Source: Fieldwork, 2019

The analysis of data obtained shows specific impact of piracy on the fishing industry. The result, as presented in the Table 2 revealed negative effects of piracy on sea business (fishing activities). The RSquared of $0.795(79.5 \%)$ and the $p$-value shows that the effect of piracy/sea robberies on fishing 
activities in Lagos State is highly significant, contributing to $79.5 \%$ of sea business problem in Lagos state. Sea piracy affects sea faring and fishing business significantly in Lagos State. Result indicates that when incidence of sea robberies/piracy is not properly managed or curbed, the success of fishing activities/sea business operation will be grossly affected negatively.

\section{DISCUSSION OF FINDINGS}

According to the research, the shoreline inlets of pirates within Lagos waters were identified and mapped with the aid of ArcGIS software which was discovered to exist in triumvirate in what was termed "the triad axis of maritime terrorism". These shoreline inlets are the operational base of piratical activities in Lagos waters. A notion that was strongly collaborated by NIMASA, NPA and Nigerian Navy. The analysis of data obtained revealed a somewhat adverse impact of piracy on the fishing industry. The result revealed negative effects of piracy on sea business (fishing activities). The R-Squared of $0.795(79.5 \%)$ and the $p$-value shows that the effect of piracy/sea robberies on fishing activities in Lagos State is highly significant, contributing to $79.5 \%$ of sea business problem in Lagos state. The Result impliedly indicates that if the incidence of sea robberies/piracy is not properly managed or curbed, the success of fishing activities/sea business operation may be unascertainable in the near future. From the $\mathrm{R} 2$ value it implies that the pirate attacks can explain as $79.5 \%$ of variation in the setback experienced by the fishing industry in Lagos. It also shows that sea piracy effects sea faring and fishing business significantly in Lagos State.

\section{CONCLUSION}

Conclusively, the study focused on evaluation of piratical activities in Lagos Waterways and Creeks. It was discovered that piracy incidences are notable in the Lagos waters as supported by both the descriptive analysis and the result. The study establishes that incidence of piracy and locational advantage has a functional relationship. The study also confirms negative effects of piracy on sea businesses particularly fishing activities which were the crux of this investigation. It was as laid to rest that the federal government and indeed the Lagos state governments are doing enough to curb the menace of piracy on Lagos waterways while on-going political instability, amongst others is one of the major causes of insecurity at the national level.

\section{RECOMMENDATIONS}

- Nigerian government should evolve sound resource management and equitable allocative practices to leverage the enormous natural resources and oil affluence to effectively address the cacophony 
of economic afflictions - such as widespread poverty, unemployment, marginalization, destitution and environmental degradation - that contributed to citizens resorting to crime.

- All viable and active merchant vessels should have some military or para-military personnel on board to coordinate security, muster and foster counter piracy measures, and enlighten crew members.

- A comprehensive, integrated, coordinated and proactive inter- security forces (Army, Airforce, Navy) among other relevant agencies should be put in place, funded as well as invest more resources in intelligence gathering and information sharing in gathering evidence on the modus operands of pirates in Nigerian territorial waterways and creeks to aid prosecution and effective counter piracy campaigns.

- The Nigerian government should ensure total compliance and implementation with all international safety measures such as GMDSS, ISPS code, SOLAS ISM, PORT STATE CONTROL (PSC) as well as installation of ShipLoc, ShipAlarm on all vessels in order to curb the ravaging monster called piracy thereby enhancing maritime security and coordination.

- The United Nations, international community, continental and regional bodies such as African Union, ECCAS and ECOWAS should evolve a common maritime patrol and interdiction mechanism, sustain efforts at the capacity building of maritime security forces in Gulf of Guinea states, and beyond to support the states or any agreed regional maritime security mechanism with platforms and equipment's to enhance their presence at sea well as demonstration of strong political will and commitment to prosecute diligently and punish sea pirates (persons, groups or organizations) financing and facilitating illicit piracy in the maritime domain by the governments of Gulf of Guinea states.

\section{REFERENCES}

Adedeji O.A, Okocha R.C. (n. 4). "Pirates Paralyze Nigeria's Fishing Industry," Maritime Terrorism Research Center, 14 February 2008 http://www.maritimeterrorism.com/2008/02/14/pirates-paralyzenigerias-fishing-industry/accessed 7 February 2015.

Anene, L. (2006). 'Gulf of Guinea: A Growing Strategic Profile', Nigerian Army Quarterly Journal, 2(1):39-51

Barrios, C. (2013). Fighting Piracy in the Gulf of Guinea. Offshore and onshore (Brief No. 20). Paris: EUISS. http://www.iss.europa.eu/uploads/media/Brief_20.pdf

Chatham House Conference Report, March 2013 and Angola and the Gulf of Guinea: Towards an Integrated Maritime Strategy, Conference Report, November 2012, http://www.chathamhouse.org/sites/default/files/public/Research/Africa/0312confreport_maritimesecurity .pdf. 
Cosby, P.C (2000). Methods in behavioral Research. California: Mayfield Publishing Company.

Onuoha, F.C. (2010) "Geo-Strategy of Oil in the Gulf of Guinea: Implications for Regional Stability", Journal of Asian and African Studies, 45(3): 369-384.

Piracy report (2017). Piracy: Nigerian Fishing Industry at Risk. http://piracyreport.co.za/Piracy_Nigerian_Fishing_Industry_at_Risk.html

The guardian newspaper (2019). NIMASA challenges piracy reports on Nigerian waters. https://guardian.ng/business-services/nimasa-challenges-piracy-reports-on-nigerian-waters/

UNODC. (2013). Transnational Organized Crime in West Africa: A Threat Assessment. Vienna: UNODC. 